\title{
Critical appraisal of rotigotine transdermal system in management of Parkinson's disease and restless legs syndrome - patient considerations
}

This article was published in the following Dove Press journal:

Degenerative Neurological and Neuromuscular Disease

3 July 2015

Number of times this article has been viewed

\author{
Tigran Kesayan' \\ Jessica D Shaw' \\ Tracy M Jones' \\ Joseph S Staffetti' \\ Theresa A Zesiewicz'1,2 \\ 'Department of Neurology, Morsani \\ College of Medicine, University \\ of South Florida, ${ }^{2}$ Department of \\ Neurology, James A Haley VA Hospital, \\ Tampa, FL, USA
}

\begin{abstract}
Rotigotine (RTG) is a dopamine agonist that is used as mono and adjunct therapy to treat Parkinson's disease, and as therapy for moderate-to-severe restless legs syndrome. RTG is the only dopamine agonist currently available as a 24-hour/day transdermal system, providing once-a-day dosing. As a transdermal patch, RTG bypasses the gastrointestinal tract, making it a treatment option for patients with dysphagia. The use of RTG also avoids the need to schedule administration of medication around meals. This review provides a critical appraisal of RTG as treatment of Parkinson's disease and RLS.
\end{abstract}

Keywords: rotigotine, dopamine agonist, Parkinson's disease, restless legs syndrome

\section{Introduction}

Parkinson's disease (PD) and restless legs syndrome (RLS) are commonly encountered movement disorders that are treated with dopamine agonists (DAs), medications that directly bind to cerebral dopamine receptors. Current DAs used for PD and RLS include pramipexole, ropinirole, and rotigotine (RTG). Side effects of levodopa, including motor fluctuations and dyskinesia in PD, and augmentation in RLS, led to the development of DAs used for treating these conditions.

RTG is the only DA currently available as a 24 -hour/day transdermal system, and may offer improvements in patient compliance compared to other treatments. This review will offer a critical appraisal of RTG as treatment in PD and RLS.

\section{Pharmacology}

RTG is a non-ergot DA at D1-D5 receptors, as well as 5-HT1A serotonergic, and $\alpha-2$ adrenergic receptors. ${ }^{1-4}$ Binding and functional assessments of RTG with recombinant receptors demonstrate a high affinity for D3 and D2 receptors, and is best described as a D3/D2/D1 receptor agonist. ${ }^{1,4}$ RTG, (6S)-6-(propyl[2-\{2-thienyl\}ethyl]amino)5,6,7,8-tetrahydro-1-naphthalenol, has a molecular weight of $315.48 \mathrm{Da}$ and its empirical formula is $\mathrm{C}_{19} \mathrm{H}_{25}$ NOS. ${ }^{1,5}$ Figure 1 shows the structural representation of RTG. It is available only in a transdermal patch form, which is composed of a backing film made of an aluminized polyester film with a pigment coat. A self-adhesive drug matrix layer contains the active ingredient along with ascorbyl palmitate, povidone, silicone adhesive, sodium metabisulfite, and DL- $\alpha$-tocopherol as inactive ingredients. ${ }^{5}$

RTG is formulated in a transdermal system, with a terminal half-life of 5-7 hours. ${ }^{6}$ RTG is $90 \%$ bound to plasma proteins, and steady-state plasma concentration occurs within 2-3 days of drug initiation. ${ }^{5}$ No dose adjustment is required for renal impairment, including patients on dialysis.
Correspondence: Theresa A Zesiewicz University of South Florida Department of Neurology, I290I Bruce B Downs Boulevard, MDC Box 55, Tampa, FL 33612, USA

Tel +l 8I 39745909

Fax + I 8I 39748032

Email tzesiewi@health.usf.edu 
RTG is approved by the US Food and Drug Administration (FDA) as monotherapy to treat early-stage PD, adjunct therapy for advanced-stage PD, and as treatment for moderate-to-severe primary RLS. RTG doses for treatment of early-stage PD monotherapy range from $2 \mathrm{mg} / 24$ hours to $6 \mathrm{mg} / 24$ hours, with recommended titration of $2 \mathrm{mg} / 24$ hours weekly. ${ }^{5}$ For adjunct therapy in advanced-stage PD, RTG may be started at $4 \mathrm{mg} / 24$ hour period and titrated up weekly by an additional $2 \mathrm{mg} / 24$ hour period, with a maximum recommended dose of $16 \mathrm{mg} / 24$ hours. $^{7}$ The effective dose range for treatment of RLS with RTG ranges from $1 \mathrm{mg} / 24$ hours to $3 \mathrm{mg} / 24$ hours..$^{8-11}$ When discontinuing RTG in PD patients, the dose should be reduced by no more than $2 \mathrm{mg} / 24$ hours every other day. In RLS, the dose should be decreased by $1 \mathrm{mg} / 24$ hours every other day.

The RTG patch needs to be replaced every 24 hours. It may be applied at various body areas including the shoulder, upper arm, hip, flank, abdomen, and thigh, preferably at approximately the same time each day. Patients are required to firmly hold the patch with the palm of their hands for 30 seconds to ensure good contact between the skin and the patch. Patients can bathe, shower, or swim while wearing the RTG patch. Precautions for wearing the RTG patch include use of heating pads, electric blankets, heat lamps, saunas, hot tubs, heated water beds, and direct sunlight that can cause increased amounts of RTG to be absorbed. The RTG patch should not be worn when patients receive magnetic resonance imaging scans or cardioversion, as a burn can occur at the site of the patch. Because the RTG patch contains sodium metabisulfites, it may cause an allergic reaction in patients who are sensitive to sulfites. RTG use may result in application site irritation, which typically resolves upon removal of the patch. ${ }^{5}$

Other potential side effects of transdermal RTG include nausea, vomiting, headache, dizziness, somnolence, and fatigue. Impulse control disorders (ICDs) including gambling, eating, abnormal buying, and abnormal sexual behaviors, can occur with use of all DAs. ${ }^{12,13}$ However, one recent multicenter study showed that RTG led to a lower incidence of ICDs than other DAs, and can be better tolerated in patients who are prone to ICDs. ${ }^{12,13}$ Use of DAs, including RTG, can result in patients falling asleep during activities of daily living, hallucinations, and psychosis or worsening psychoticlike behavior. Patients should be frequently monitored for all adverse events by continually reassessing them during titration and at regular intervals throughout treatment.

\section{PD and RTG}

PD is a progressive, neurodegenerative disorder caused by a loss of dopaminergic neurons in the substantia nigra pars compacta along with involvement in noradrenergic, serotonergic, and cholinergic systems..$^{14}$ The degree of dopaminergic cell loss in the substantia nigra pars compacta correlates with the duration of disease, and the greatest cell loss occurs in the caudal and mediolateral parts with progression along rostral, medial, and dorsal axes. ${ }^{15}$ Studies have also demonstrated a loss of dopaminergic cells to a lesser degree in the ventral tegmental area as well as retrobulbar areas in the brains of those with PD. ${ }^{16,17}$ The cardinal symptoms of PD are tremor, rigidity, bradykinesia, and postural instability. Nonmotor symptoms (NMS) also occur in most PD patients, including sleep, mood, autonomic, and cognitive disorders, among others. ${ }^{18,19}$ Treatment for PD motor symptoms includes replacement of dopamine by carbidopa/ levodopa, DAs, monoamine oxidase-B (MAO-B) inhibitors, catechol-O-methyltransferase (COMT) inhibitors, amantadine, and anticholinergic medications.

Several large, randomized controlled trials have found RTG to be safe and effective in treating motor symptoms in early- and advanced-stage PD (Table 1). ${ }^{2,20-27}$ One study compared the effectiveness of RTG to ropinirole and placebo in 561 early-PD patients. ${ }^{2}$ The primary efficacy variable was at least a $20 \%$ responder rate on the total score of the Unified Parkinson's Disease Rating Scale (UPDRS) parts II and III, while the secondary efficacy variable was the change in total UPDRS parts II and III scores at endpoint relative to baseline. There were significantly higher responder rates in patients randomized to receive RTG than in those who took placebo $(P<0.0001)$. The change in total UPDRS parts II and III scores from baseline to the end of a 4-week maintenance phase was -7.2 points in the RTG group $(P<0.0001),-11.0$ points in the ropinirole group, $(P<0.0001)$, and -2.2 points for placebo. The mean RTG dose was $8 \mathrm{mg} / 24$ hours, while the mean ropinirole dose was $14.1 \mathrm{mg} /$ day. Watts et al evaluated the effect of RTG on motor symptoms in 181 early-PD patients in a 6-month randomized, placebo-controlled study. ${ }^{23}$ Efficacy measures included the change in the UPDRS scores (parts II and III) from baseline to endpoint. The RTG group had a 3.98 (standard deviation [SD] 0.71)-point improvement in the UPDRS II and III scores compared to a 1.31 (SD 0.96)-point worsening in the placebo group $(P<0.001)$. The mean dose of RTG was $5.7 \mathrm{mg} / 24$ hours. $^{23}$

The PREFER study evaluated the use of RTG as adjunct medication in advanced-PD patients. ${ }^{26}$ Three hundred and forty-one patients were randomized to receive RTG $8 \mathrm{mg} / 24$ hours, $12 \mathrm{mg} / 24$ hours, or placebo for 28 weeks. The primary efficacy measure was the change in the number of daily hours in the "off" state. A reduction in the 
Table I Efficacy of RTG in early and advanced PD

\begin{tabular}{|c|c|c|c|c|}
\hline & \multirow[t]{2}{*}{ Dose } & \multirow[t]{2}{*}{$\mathbf{n}$} & \multicolumn{2}{|c|}{ Change from baseline \pm SD (P-value) } \\
\hline & & & UPDRS II ADL & UPDRS III motor \\
\hline \multicolumn{5}{|l|}{ Early PD } \\
\hline \multirow{3}{*}{ Güldenpfennig et $\mathrm{a}^{20}$} & $18 \mathrm{mg}$ & 25 & $-2.84 \pm 3.45(0.0004)$ & $-4.88 \pm 5.56(0.0002)$ \\
\hline & $<18 \mathrm{mg}$ & 4 & $-2.25 \pm 2.36(0.1622)$ & $-3.00 \pm 3.56(0.167 I)$ \\
\hline & Plo & 0 & - & - \\
\hline \multirow[t]{2}{*}{ Jankovic et $\mathrm{al}^{21}$} & $5.7 \mathrm{mg}^{\mathrm{a}}$ & 177 & $-0.39 \pm 0.26(0.002)$ & $-3.58 \pm 0.54(0.001)$ \\
\hline & Plo & 96 & $0.92 \pm 0.35(0.002)$ & $0.38 \pm 0.73(0.001)$ \\
\hline \multirow[t]{5}{*}{ Parkinson Study Group ${ }^{22}$} & $4.5 \mathrm{mg}$ & 49 & $-0.04(0.94)$ & $-0.90(0.44)$ \\
\hline & $9 \mathrm{mg}$ & 47 & $-0.84(0.11)$ & $-1.88(0.11)$ \\
\hline & $13.5 \mathrm{mg}$ & 48 & $-0.92(0.08)$ & $-3.91(0.001)$ \\
\hline & $18 \mathrm{mg}$ & 51 & $-1.56(0.003)$ & $-3.82(0.001)$ \\
\hline & Plo & 47 & - & - \\
\hline \multirow[t]{2}{*}{ Watts et $\mathrm{al}^{23}$} & $5.7 \mathrm{mg}^{\mathrm{a}}$ & 180 & $-0.30 \pm 3.54$ & $-3.50 \pm 7.26$ \\
\hline & Plo & 96 & - & - \\
\hline \multirow[t]{2}{*}{ Giladi et al ${ }^{2}$} & $8 \mathrm{mg}^{\mathrm{b}}$ & 215 & $-2.1^{c}$ & $-5.2^{\mathrm{c}}$ \\
\hline & Plo & 118 & -0.1 & -2.1 \\
\hline \multirow[t]{2}{*}{ Trenkwalder et al ${ }^{25}$} & $2-16 \mathrm{mg}$ & 178 & $-2.6 \pm 3.6$ & $-7.0(0.002)$ \\
\hline & Plo & 89 & $-1.3 \pm 3.4$ & -3.9 \\
\hline \multicolumn{5}{|l|}{ Advanced PD } \\
\hline \multirow[t]{3}{*}{ LeWitt et al ${ }^{26}$} & $8 \mathrm{mg}$ & 113 & $-3.1(0.004)$ & $-6.8(0.0185)$ \\
\hline & $12 \mathrm{mg}$ & 109 & $-3.2(0.0023)$ & $-8.7(0.0006)$ \\
\hline & Plo & 119 & -0.5 & -3.4 \\
\hline \multirow[t]{2}{*}{ Poewe et $\mathrm{al}^{27}$} & $9-36 \mathrm{mg}$ & 201 & $-4.2 \pm 4.5(<0.000 \mathrm{I})$ & $-8.7 \pm 8.0(<0.000 \mathrm{I})$ \\
\hline & Plo & 100 & $-2.0 \pm 4.3(<0.0001)$ & $-4.3 \pm 9.3(<0.0001)$ \\
\hline
\end{tabular}

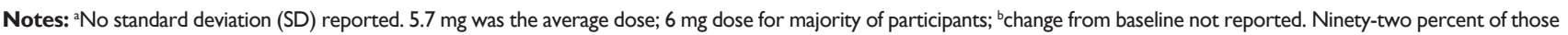
in the RTG group were treated with this dose in the maintenance phase and $8 \%$ had lower doses; there was no SD reported for UPDRS II or III separately; however, the combined UPDRS part III + part II scores were significantly more improved compared to placebo at the end of the maintenance phase $(P<0.000 \mathrm{I})$; ' there was no SD reported for UPDRSII or III separately, however the combined UPDRS part III + part II scores were significantly more improved compared to placebo at the end of the maintenance phase $(P<0.000$ I). Abbreviations: RTG, rotigotine; PD, Parkinson's disease; UPDRS II, Unified Parkinson's Disease Rating Scale part II (activities of daily living); UPDRS III, Unified Parkinson's Disease Rating Scale part III (motor examination); Plo, placebo.

"off" time was reported at the end of the maintenance period, consisting of -2.7 hours in the RTG $8 \mathrm{mg} / 24$ hour group $(P<0.001),-2.1$ hours in the RTG $12 \mathrm{mg} / 24$ hour group $(P<0.001)$, and -0.9 hours in patients taking placebo. Improvements in the UPDRS II subtotal scores were -3.1 points in the RTG $8 \mathrm{mg} / 24$ hour group ( $P=0.0004),-3.2$ points in the RTG $12 \mathrm{mg} / 24$ hour group ( $P=0.0023)$, and -0.5 points for the placebo group. ${ }^{26}$

The Randomized Evaluation of the 24-hour Coverage: Efficacy of Rotigotine (RECOVER) study was a 12-week multicenter, multinational, double-blind, placebo-controlled, randomized trial that randomized 287 PD patients with early-morning motor symptoms to receive either RTG $(2-16 \mathrm{mg} / 24$ hours; $\mathrm{n}=190)$ or placebo $(\mathrm{n}=97) .{ }^{25}$ Eighty-one percent of the participants in the RTG group and $82 \%$ of those in the placebo group were taking immediate release L-dopa and had been on a stable dose for at least 28 days. ${ }^{25}$ The primary study endpoints were improvements in early-morning motor function and nocturnal sleep from endpoint to baseline, measured by the UPDRS part III and the modified Parkinson's Disease Sleep Scale-2 (PDSS-2), respectively. Inclusion criteria included patients with idiopathic PD, Hoehn and Yahr stages 1 through 4, who were deemed by the investigators to have "unsatisfactory control of early-morning motor symptoms". The study found significant improvements with RTG use compared to placebo in both UPDRS part III (treatment difference: $-3.55 ; 95 \%$ confidence interval $[\mathrm{CI}]-5.37,-1.73$; $P=0.0002$ ) and PDSS-2 (treatment difference: $-4.26 ; 95 \% \mathrm{CI}$ $-6.08,-2.45 ; P<0.0001)$. The most frequently reported adverse events from RTG were nausea (21\%), application site reactions (15\%), and dizziness (10\%). (Adverse effects associated with RTG for the randomized, double-blind trials are listed in Table 2). ${ }^{2,4,22,23,25-27}$

A recent randomized, double-blind, placebo-controlled study of the efficacy of RTG in patients with advanced PD produced similar data, demonstrating a reduction of UPDRS part III scores of $-10.1 \pm 9.0$ for the RTG group and $-4.4 \pm 7.4$ in the placebo group $(P<0.001)$ along with a reduction of offtime in the PD group $(P<0.014) .{ }^{28}$ The side-effect profile was similar to that reported in other studies with $19.5 \%$ of those in the RTG group experiencing nausea compared to $5.7 \%$ in the placebo group; other side effects were constipation $10.3 \%$ and $1.1 \%$, dyskinesia $13.8 \%$ and $8.0 \%$, somnolence $13.8 \%$ and $1.1 \%$ in the RTG group and the placebo group, respectively. 
Table 2 Percentage of participants with side effects during randomized, double-blind studies of RTG for early and advanced PD

\begin{tabular}{|c|c|c|c|c|c|c|c|c|c|c|c|c|c|c|}
\hline & \multicolumn{2}{|c|}{$\begin{array}{l}\text { Giladi } \\
\text { et } \mathbf{a l}^{2}\end{array}$} & \multicolumn{2}{|c|}{$\begin{array}{l}\text { Poewe } \\
\text { et } \mathbf{a l}^{27}\end{array}$} & \multicolumn{2}{|c|}{$\begin{array}{l}\text { Jankovic } \\
\text { et } \mathrm{al}^{21}\end{array}$} & \multicolumn{2}{|c|}{$\begin{array}{l}\text { Trenkwalder } \\
\text { et } \mathrm{al}^{25}\end{array}$} & \multicolumn{2}{|c|}{$\begin{array}{l}\text { Parkinson } \\
\text { Study Group }{ }^{22}\end{array}$} & \multicolumn{2}{|c|}{$\begin{array}{l}\text { Watts } \\
\text { et } \text { al }^{23}\end{array}$} & \multicolumn{2}{|c|}{$\begin{array}{l}\text { LeWitt } \\
\text { et } \mathbf{a l}^{26}\end{array}$} \\
\hline & RTG & Plo & RTG & Plo & RTG & Plo & RTG & Plo & RTG & Plo & RTG & Plo & RTG & Plo \\
\hline Application site reaction & 38 & 11 & 18 & 9 & 44 & 11 & 15 & 4 & 39 & 21 & 44 & 12 & 41 & 13 \\
\hline Headache & 10 & 8 & 4 & 5 & 16 & 9 & 7 & 5 & 17 & 13 & 16 & 9 & 9 & 8 \\
\hline Nausea & 29 & 16 & 17 & 11 & 41 & 17 & 21 & 9 & 47 & 15 & 41 & 17 & 26 & 20 \\
\hline Vomiting & 12 & 3 & - & - & 9 & I & - & - & 16 & 2 & 9 & 1 & - & - \\
\hline Fatigue & - & - & - & - & 8 & 5 & - & - & 15 & 2 & 8 & 5 & - & - \\
\hline Back pain & 7 & 8 & 6 & 4 & 6 & 3 & - & - & - & - & 6 & 3 & - & - \\
\hline Somnolence & 23 & 20 & 12 & 8 & 33 & 20 & - & - & 22 & 4 & - & - & 32 & 28 \\
\hline Dyskinesia & - & - & 12 & 3 & - & - & 8 & 4 & - & - & - & - & 15 & 7 \\
\hline Dizziness & 14 & 10 & 6 & 4 & 19 & 13 & 10 & 6 & 24 & 13 & 19 & 13 & 19 & 15 \\
\hline Hallucinations & - & - & 5 & I & - & - & - & - & - & - & - & - & 7 & 6 \\
\hline Orthostatic hypotension & - & - & 3 & 5 & - & - & - & - & - & - & - & - & 2 & 7 \\
\hline Peripheral edema & - & - & - & - & - & - & - & - & 5 & 0 & - & - & 11 & I \\
\hline Insomnia & 6 & 5 & - & - & 9 & 3 & - & - & 19 & 11 & - & - & 11 & 6 \\
\hline Tremor & - & - & - & - & 6 & 4 & - & - & - & - & 6 & 4 & - & - \\
\hline Diarrhea & 4 & 4 & - & - & 6 & 2 & - & - & 4 & 9 & 6 & 2 & - & - \\
\hline Constipation & 7 & 4 & - & - & 6 & 4 & - & - & - & - & 6 & 4 & - & - \\
\hline
\end{tabular}

Abbreviations: RTG, rotigotine; PD, Parkinson's disease; Plo, placebo.

The most prevalent side effect in the RTG group (50.6\%) was application site reaction, and $18.4 \%$ in the placebo group had similar application site reactions. ${ }^{28}$

RTG was also recently evaluated as a potential PD therapy as an add-on to an oral DA. In an open-label study, advanced-PD patients were treated with levodopa, pramipexole $(<1.5 \mathrm{mg} /$ day $)$, or ropinirole ( $<6.0 \mathrm{mg} /$ day), and RTG $(<8 \mathrm{mg} / 24$ hours) for an 8 -week treatment period. ${ }^{7}$ Ninety-three percent of the 89 patients who completed the study had a Clinical Global Impression (CGI) score of $<3$, meaning RTG did not interfere with the patient's functioning. ${ }^{7}$ The addition of RTG to the patients' current DA regimen led to a decrease in the UPDRS part III scores of $-5.3 \pm 8.3$ (95\% CI -7.1, -3.6); UPDRS II scores decreased by $-1.5 \pm 3.8(95 \% \mathrm{CI}-2.3,-0.7)$ in $\mathrm{PD}{ }^{7}$

NMS are commonly encountered in PD, and adversely affect quality of life (QoL). NMS include autonomic dysfunction, mood and cognitive issues, and sleep disorders, which tend to be under-recognized in the PD population. ${ }^{29,30}$ Both dopaminergic and nondopaminergic pathophysiologic mechanisms play a role in the NMS in $\mathrm{PD}^{31,32}$ One retrospective review found that almost $99 \%$ of $\mathrm{PD}$ patients experience NMS, including fatigue (58\%), anxiety (56\%), leg pain (38\%), insomnia (37\%), urgency and nocturia (35\%), drooling of saliva (31\%), and difficulties in maintaining concentration (31\%). ${ }^{33}$

A post hoc analysis of covariance (ANCOVA) of the RECOVER study demonstrated improvements in mood/ apathy and pain in patients taking RTG compared to those taking placebo. ${ }^{31,34}$ In the study, pain was assessed in the early morning using the 11-point Likert pain scale ("average severity of pain [of any type] over the preceding 12 hours from 0 [no pain] to 10 [worst pain ever experienced]"). ${ }^{34}$ Data from 267 patients with Likert pain data (178 RTG, 89 placebo) were analyzed. One hundred and eighty-seven patients (70\%) reported "any" pain (87 patients [33\%] reported "mild" pain, and 100 patients [37\%] reported "moderate-tosevere" pain). There was a decrease in baseline pain scores with RTG in comparison to placebo in patients with "any" pain (mean treatment difference of -0.88 [95\% CI -1.56 , -0.19 ], $P=0.013$ ), as well as in the subgroup of patients who reported "moderate-to-severe" pain (mean treatment difference of $-1.38[-2.44,-0.31], P=0.012)$.

The RECOVER study demonstrated improvement in all sleep-related questions ("disturbed sleep" $P<0.001$, "motor symptoms at night" $P<0.001$, "PD symptoms at night" $P<0.001$, and "difficulty falling asleep" $P<0.001$ ) in the PDSS-2. ${ }^{25}$ Improved sleep with RTG treatment was also demonstrated by a $61 \%$ reduction in the Mean Nocturnal Akinesia, Dystonia and Cramps Sum Score of 54 PD patients with sleep disturbance. ${ }^{35}$ In this study, more than half of the patients who reported hypersomnolence or insomnia on the UPDRS part IV at the onset of the study no longer had those symptoms at the end of the treatment phase.$^{35} \mathrm{~A}$ recent prospective, open-label, observational study showed that after 3 months of treatment with RTG (mean dose $8.9 \mathrm{mg} / 24$ hours) of 62 patients led to improved sleep fragmentation from baseline on the PDSS-2 sleep maintenance subscale (from $3.4 \pm 0.9$ to $1.9 \pm 1.4 ; P<0.0001$ ). ${ }^{36}$ RTG also significantly improved nocturnal motor symptoms 
$(P<0.0001)$, RLS-like symptoms $(P<0.005)$, and nocturia $(P=0.004) .{ }^{36}$

\section{RLS and RTG}

RLS is a neurological disorder effecting 2\%-3\% of adults. The International RLS Study Group (IRLS) criteria for the diagnosis of RLS include an uncomfortable urge to move the extremities that is worse at rest and in the evening hours, and relieved or improved by moving them. ${ }^{37}$ The differential diagnosis of RLS includes venous stasis, arthritis, cramps, druginduced akathisia, and habitual foot tapping along with causes of secondary RLS such as iron deficiency and peripheral neuropathy. ${ }^{38}$ While the exact etiology and pathophysiology of RLS is unknown, a dysfunction of the A11 dopaminergic neurons in the diencephalon may be involved. ${ }^{39}$ Current treatment options of RLS usually include DAs, levodopa, benzodiazepines such as clonazepam, and several antiepileptic medications including gabapentin.

RTG is FDA approved in the treatment of moderateto-severe RLS. Trenkwalder et al performed a 6-month, double-blind, placebo-controlled trial in 458 patients with moderate-to-severe RLS to evaluate the effect of RTG ( $1 \mathrm{mg} / 24$ hours, $2 \mathrm{mg} / 24$ hours or $3 \mathrm{mg} / 24$ hours). ${ }^{8}$ The primary endpoint was the change from baseline to end of maintenance in the IRLS rating scale total score. Use of RTG $1 \mathrm{mg} / 24$ hours resulted in a 13.7-point improvement in the IRLS total score, while RTG $2 \mathrm{mg} / 24$ hours led to a 16.2-point improvement, and RTG $3 \mathrm{mg} / 24$ hours resulted in a 16.8 point improvement, compared to an 8.6 point-improvement with placebo $\left(P<0.001\right.$ for each dose vs placebo). ${ }^{8}$ The mean change in CGI from baseline to end of maintenance phase was -2.09 at $1 \mathrm{mg},-2.41$ at $2 \mathrm{mg},-2.55$ at $3 \mathrm{mg}$, and -1.34 with placebo $\left(P<0.0001\right.$ for each dose vs placebo). ${ }^{8}$ Another 6-month randomized, double-blind, placebo-controlled trial in 505 patients with moderate-to-severe RLS reported a significant reduction in the total IRLS score and CGI scores with $2 \mathrm{mg} / 24$ hours and $3 \mathrm{mg} / 24$ hours doses of RTG compared to placebo $(P<0.001) .{ }^{10}$ The change in the IRLS score from baseline to end of maintenance was -4.5 in the $2 \mathrm{mg} / 24$ hour group, -5.2 in the $3 \mathrm{mg} / 24$ hour group, and -0.9 for placebo. There was no significant decrease in the IRLS score in the $1 \mathrm{mg} / 24$ hour group, but the lack of benefit may have been caused by a higher number of treatment- naïve (64\%), and less severely affected patients in this group. ${ }^{10}$ Another randomized, double-blind, placebo-controlled, parallel group study compared the efficacy of RTG $2 \mathrm{mg} / 24$ hours or $3 \mathrm{mg} / 24$ hours with placebo for a period of 13 weeks. ${ }^{40}$ Both doses were effective as measured by a change in IRLS scores from baseline to end of the maintenance phase; the RTG $2 \mathrm{mg} / 24$ hours dose had a 2.8 point decrease and the 3 $\mathrm{mg} / 24$ hours dose had a 3.1 point decrease in IRLS scores $(P<0.05){ }^{40}$ Table 3 summarizes the efficacy of RTG from several trials, and Table 4 lists the adverse events associated with these trials. ${ }^{8-10,24,40,41}$

The potential for augmentation is often a consideration when choosing treatment regimens for patients with RLS. Patients treated with levodopa find that the dose gradually becomes inadequate for symptom control, wearing off sooner, resulting in the return of symptoms with increased severity and often appearing in previously unaffected limbs. ${ }^{42}$ Studies indicate that RTG and other DAs have a lower rate of augmentation in the treatment of RLS compared to levodopa. ${ }^{43,44}$ In a review of two RLS and RTG augmentation studies, $8.2 \%$ of subjects in a double-blind trial and $9.7 \%$ of subjects in an open-label trial met the Max Planck Institute criteria for augmentation; however, of the two trials only $1.5 \%$ and $2.9 \%$ of augmentation cases (respectively) were clinically relevant. ${ }^{44}$ In an open-label extension study conducted over a 5-year period of RTG treatment for moderate-to-severe RLS, Oertel et al recorded augmentation in 5\% of patients being treated with $1-3 \mathrm{mg} / 24$ hours and $8 \%$ of patients treated with $4 \mathrm{mg} / 24$ hours. ${ }^{45}$ Augmentation rates of up to $82 \%$ have been reported in RLS patients taking levodopa..$^{43}$ Open-label extension studies of RTG for the treatment of RLS suggest that the efficacy of treatment may be maintained for up to 5 years, and RTG continues to be safe and tolerable, with a similar side-effect profile as seen in the double-blinded, placebo-controlled studies. These studies evaluated the efficacy, safety, and tolerability of RTG for the treatment of RLS for $1-5$ years past the blinded randomized control trials. ${ }^{45-47}$

\section{QoL}

RTG has been shown to have a positive effect on QoL in both PD and RLS patients, with significant improvements in emotional well-being, mobility, and activities of daily living. ${ }^{27,48}$ The Clinical Efficacy of Pramipexole And Transdermal Rotigotine in Advanced PD (CLEOPATRA-PD) trial was a double-blind, controlled study of 506 levodopa-treated PD patients who experienced daily "off" time, and who were randomized to receive pramipexole, RTG, or placebo. ${ }^{27}$ Patients who were treated with pramipexole or RTG had significantly improved QoL scores compared to those given placebo as measured by the mobility, activities of daily living, and emotional well-being domains of the 39-item Parkinson's Disease Questionnaire (PDQ-39). Another study performed in 458 RLS patients found an improvement in QoL with RTG use over a 6-month 
Table 3 Efficacy of RTG in RLS - change from baseline \pm SD ( $P$-value)

\begin{tabular}{|c|c|c|c|c|}
\hline Study, dose & $\mathbf{n}$ & $\begin{array}{l}\text { IRLS total score } \pm \\
\text { SD (P-value) }\end{array}$ & $\begin{array}{l}\text { CGI-I score } \pm \\
\text { SD (P-value) }\end{array}$ & $\begin{array}{l}\text { PSQI total score } \pm \\
\text { SD (P-value) }\end{array}$ \\
\hline \multicolumn{5}{|l|}{ Inoue et $\mathrm{al}^{40}$} \\
\hline $2 \mathrm{mg}$ & 95 & $-14.3 \pm 8.9(0.030)$ & - & $-3.1 \pm 3.2(0.188)$ \\
\hline $3 \mathrm{mg}$ & 94 & $-14.6 \pm 9.0(0.016)$ & - & $-3.2 \pm 3.3(0.112)$ \\
\hline Plo & 95 & $-11.6 \pm 8.2$ & - & $-2.5 \pm 2.4$ \\
\hline \multicolumn{5}{|l|}{ Oertel et $\mathrm{al}^{24}$} \\
\hline $2 \mathrm{mg}^{\mathrm{a}}$ & 41 & $-16.5 \pm 9.3$ & $-2.7 \pm 1.4$ & - \\
\hline Plo & 20 & $-9.9 \pm 9.9$ & $-1.7 \pm 1.5$ & - \\
\hline \multicolumn{5}{|l|}{ Hening et $\mathrm{a}^{10}$} \\
\hline $0.5 \mathrm{mg}$ & 98 & $-10.9 \pm 8.9(0.0682)$ & $4.7 \pm 0.8(0.0603)$ & - \\
\hline $\mathrm{I} \mathrm{mg}$ & 99 & $-11.1 \pm 9.3(0.0535)$ & $4.6 \pm 0.7(0.0857)$ & - \\
\hline $2 \mathrm{mg}$ & 95 & $-13.4 \pm 9.2(0.0002)$ & $4.7 \pm 0.8(0.0007)$ & - \\
\hline $3 \mathrm{mg}$ & 103 & $-14.3 \pm 9.4(<0.0001)$ & $4.7 \pm 0.8(<0.000 \mathrm{I})$ & - \\
\hline Plo & 99 & $-9.0 \pm 7.7$ & $4.7 \pm 0.6$ & - \\
\hline \multicolumn{5}{|c|}{ Trenkwalder et $\mathrm{a}^{8}$} \\
\hline I mg & 148 & $-14.0 \pm 0.8(<0.0001)$ & $-2.13 \pm 0.12(<0.0001)$ & - \\
\hline $2 \mathrm{mg}$ & 96 & $-16.4 \pm 1.0(<0.0001)$ & $-2.4 \mathrm{I} \pm 0.14(<0.000 \mathrm{I})$ & - \\
\hline $3 \mathrm{mg}$ & 92 & $-16.8 \pm 1.1(<0.0001)$ & $-2.55 \pm 0.17(<0.0001)$ & - \\
\hline Plo & 111 & $-8.7 \pm 0.9$ & $-1.37 \pm 0.15$ & - \\
\hline \multicolumn{5}{|l|}{ Oertel et $\mathrm{a}^{9}$} \\
\hline $0.5 \mathrm{mg}$ & 50 & $-10.5 \pm 9.2(0.2338)$ & $-1.6 \pm 1.4$ & - \\
\hline $\mathrm{l} \mathrm{mg}$ & 64 & $-15.3 \pm 10.0(0.0004)$ & $-2.2 \pm 1.5(<0.05)$ & - \\
\hline $2 \mathrm{mg}$ & 49 & $-15.7 \pm 9.5(0.0003)$ & $-2.4 \pm 1.3(<0.05)$ & - \\
\hline $3 \mathrm{mg}$ & 64 & $-17.3 \pm 10.5(<0.0001)$ & $-2.7 \pm 1.6(<0.05)$ & - \\
\hline $4 \mathrm{mg}$ & 53 & $-14.9 \pm 10.3(0.0013)$ & $-2.3 \pm 1.5(<0.05)$ & - \\
\hline Plo & 53 & $-9.3 \pm 9.6$ & $-1.5 \pm 1.4$ & - \\
\hline \multicolumn{5}{|c|}{ Stiasny-Kolster ${ }^{41}$} \\
\hline $1.125 \mathrm{mg}$ & 19 & $-10.5 \pm 2.0$ & - & - \\
\hline $2.25 \mathrm{mg}$ & 13 & $-12.3 \pm 2.3$ & - & - \\
\hline $4.5 \mathrm{mg}$ & 17 & $-15.7 \pm 1.9$ & - & - \\
\hline Plo & 14 & $-8.0 \pm 2.2$ & - & - \\
\hline
\end{tabular}

Note: ${ }^{\text {aA }}$ mean dose of RTG in the treatment group was reported as $2.1 \mathrm{mg} / 24$ hours.

Abbreviations: RTG, rotigotine; RLS, restless legs syndrome; SD, standard deviation; IRLS, International Restless Legs Syndrome Study Group severity rating scale; CGI-I, Clinical Global Impressions item-I; PSQI, Pittsburgh Sleep Quality Index; Plo, placebo.

period as measured by the RLS QoL scale. ${ }^{8}$ Patients taking $3 \mathrm{mg} / 24$ hours of RTG were reported to have a 17.5-point improvement (SD 14.2) in the RLS QoL questionnaire, those taking $2 \mathrm{mg} / 24$ hours had a 15.7-point improvement (SD 12.8), and patients given $1 \mathrm{mg} / 24$ hours had a 13.1 (SD 14.8)-point improvement (the placebo group demonstrated a 7.3-point improvement [SD 13.5] during the same time frame). ${ }^{8}$

\section{Patient treatment considerations}

RTG has been shown to be a safe and effective treatment for motor symptoms in both PD and RLS. As a brand name medication, it is more costly than other generic DAs, raising the question of RTG cost-effectiveness. There are few studies that have assessed this issue. Benhaddi et al assessed the cost-effectiveness of RTG compared to placebo, ropinirole, and pramipexole as treatment of early-stage PD using a cost-utility analysis from the National Health Service of
Scotland. ${ }^{49}$ RTG was found to be a cost-effective treatment in advanced PD from the payer's perspective..$^{50}$ In this study, the average cost-effectiveness ratio (cost of study medication to costs associated with medication side effects) was lower for RTG at doses of $4 \mathrm{mg} / 24$ hours, $6 \mathrm{mg} / 24$ hours, and $8 \mathrm{mg} / 24$ hours (\$923, $\$ 1,136$, and $\$ 1,374$, respectively) and $4.5 \mathrm{mg} /$ day of pramipexole $(\$ 1,585) . .^{50}$

There are few, if any, direct comparator studies of RTG with other DAs in terms of efficacy. A recent randomized, double-blind, double-dummy study compared the efficacy of RTG along with levodopa vs ropinirole and levodopa in a group of 420 PD patients with inadequate motor symptom control. ${ }^{51}$ RTG was shown to be better than placebo, but there was no difference between RTG and ropinorole. ${ }^{51}$ Several other studies included RTG and other DAs as treatment of PD and RLS, but were not powered sufficiently to determine non-inferiority. What then, are some circumstances that 
Table 4 Side effects present in participants (\%) during randomized, double-blinded, placebo-controlled trials

\begin{tabular}{|c|c|c|c|c|c|c|c|c|c|c|c|c|c|}
\hline \multirow[t]{2}{*}{ Side effect } & \multirow[t]{2}{*}{ Dose } & \multicolumn{2}{|c|}{ Inoue et $\mathrm{al}^{40}$} & \multicolumn{2}{|c|}{$\begin{array}{l}\text { Hening } \\
\text { et } \mathrm{al}^{10}\end{array}$} & \multicolumn{2}{|c|}{$\begin{array}{l}\text { Trenkwalder } \\
\text { et } \mathrm{al}^{8}\end{array}$} & \multicolumn{2}{|c|}{$\begin{array}{l}\text { Oertel } \\
\text { et } \mathrm{al}^{9}\end{array}$} & \multicolumn{2}{|c|}{$\begin{array}{l}\text { Oertel } \\
\text { et } \mathrm{al}^{24, \mathrm{a}}\end{array}$} & \multicolumn{2}{|c|}{$\begin{array}{l}\text { Stiasny- } \\
\text { Kolster }^{41, b}\end{array}$} \\
\hline & & RTG & Plo & RTG & Plo & RTG & Plo & RTG & Plo & RTG & Plo & RTG & Plo \\
\hline Application & $0.5 \mathrm{mg}$ & - & 7.4 & 22.2 & 5.0 & - & - & 9.8 & 1.8 & - & 4.8 & - & 28.6 \\
\hline \multirow[t]{4}{*}{ site reaction } & $\mathrm{I} \mathrm{mg}$ & - & - & 17 & - & 35.0 & 2.0 & 15.6 & - & - & - & 17.6 & - \\
\hline & $2 \mathrm{mg}$ & 42.1 & - & 34.3 & - & 41.0 & - & 16.3 & - & 17.4 & - & 38.5 & - \\
\hline & $3 \mathrm{mg}$ & 50.0 & - & 34 & - & 52.0 & - & 20 & - & - & - & - & - \\
\hline & $4 \mathrm{mg}$ & - & - & - & - & - & - & 25 & - & - & - & 26.3 & - \\
\hline \multirow[t]{5}{*}{ Headache } & $0.5 \mathrm{mg}$ & - & 0 & 14.1 & 8.0 & - & - & 11.8 & 7.3 & - & 14.3 & - & 7.1 \\
\hline & $\mathrm{l} \mathrm{mg}$ & - & - & 12 & - & 10.0 & 7.0 & 7.8 & - & - & - & 11.8 & - \\
\hline & $2 \mathrm{mg}$ & 5.3 & - & 10.1 & - & 13.0 & - & 2 & - & 17.4 & - & 38.5 & - \\
\hline & $3 \mathrm{mg}$ & 2.1 & - & 10.4 & - & 16.0 & - & 4.6 & - & - & - & - & - \\
\hline & $4 \mathrm{mg}$ & - & - & - & - & - & - & 12.5 & - & - & - & 21.1 & - \\
\hline \multirow[t]{5}{*}{ Nausea } & $0.5 \mathrm{mg}$ & - & 9.5 & 13.1 & 10.0 & - & - & 5.9 & 9.1 & - & 4.8 & - & 14.3 \\
\hline & $\mathrm{l} \mathrm{mg}$ & - & - & 20 & - & 9.0 & - & 9.4 & - & - & - & 0.0 & - \\
\hline & $2 \mathrm{mg}$ & 33.7 & - & 18.2 & - & 21.0 & - & 6.1 & - & 21.7 & - & 7.7 & - \\
\hline & $3 \mathrm{mg}$ & 43.6 & - & 20.8 & - & 18.0 & - & 24.6 & - & - & - & - & - \\
\hline & $4 \mathrm{mg}$ & - & - & - & - & - & - & 23.2 & - & - & - & 5.3 & - \\
\hline \multirow[t]{5}{*}{ Fatigue } & $0.5 \mathrm{mg}$ & - & - & 10.1 & 4.0 & - & - & 3.9 & 9.1 & - & 9.5 & - & 0.0 \\
\hline & $\mathrm{I} \mathrm{mg}$ & - & - & 3 & - & 7.0 & 9.0 & 4.7 & - & - & - & 0.0 & - \\
\hline & $2 \mathrm{mg}$ & - & - & 7.1 & - & 15.0 & - & 6.1 & - & 8.7 & - & 0.0 & - \\
\hline & $3 \mathrm{mg}$ & - & - & 6.6 & - & 11.0 & - & 10.8 & - & - & - & - & - \\
\hline & $4 \mathrm{mg}$ & - & - & - & - & - & - & 7.1 & - & - & - & 10.5 & - \\
\hline \multirow[t]{5}{*}{ Pruritus } & $0.5 \mathrm{mg}$ & - & - & 9.1 & 2.0 & - & - & 5.9 & 1.8 & - & - & - & 7.1 \\
\hline & $\mathrm{I} \mathrm{mg}$ & - & - & 2 & - & - & - & 3.1 & - & - & - & 5.9 & - \\
\hline & $2 \mathrm{mg}$ & - & - & 3 & - & - & - & 0 & - & - & - & 15.4 & - \\
\hline & $3 \mathrm{mg}$ & - & - & 7.5 & - & - & - & 10.8 & - & - & - & - & - \\
\hline & $4 \mathrm{mg}$ & - & - & - & - & - & - & 3.6 & - & - & - & 0.0 & - \\
\hline \multirow[t]{5}{*}{ Hyperhidrosis } & $0.5 \mathrm{mg}$ & - & - & - & - & - & - & - & - & - & - & - & 0.0 \\
\hline & $\mathrm{I} \mathrm{mg}$ & - & - & - & - & 5.0 & 3.0 & - & - & - & - & 0.0 & - \\
\hline & $2 \mathrm{mg}$ & - & - & - & - & 6.0 & - & - & - & - & - & 0.0 & - \\
\hline & $3 \mathrm{mg}$ & - & - & - & - & 4.0 & - & - & - & - & - & - & - \\
\hline & $4 \mathrm{mg}$ & - & - & - & - & - & - & - & - & - & - & 10.5 & - \\
\hline \multirow[t]{5}{*}{ Somnolence } & $0.5 \mathrm{mg}$ & - & 2.1 & 8.1 & 6.0 & - & - & - & - & - & 9.5 & - & - \\
\hline & $\mathrm{l} \mathrm{mg}$ & - & - & 10.0 & - & - & - & - & - & - & - & - & - \\
\hline & $2 \mathrm{mg}$ & 10.5 & - & 13.1 & - & - & - & - & - & 10.9 & - & - & - \\
\hline & $3 \mathrm{mg}$ & - & - & 15.1 & - & - & - & - & - & - & - & - & - \\
\hline & $4 \mathrm{mg}$ & - & - & - & - & - & - & - & - & - & - & - & - \\
\hline
\end{tabular}

Notes: a The study did not report the association of adverse events (AE) in relation to the dose of RTG. A mean dose of RTG in the treatment group was reported as $2.1 \mathrm{mg} / 24$ hours; bdoses were $1.125 \mathrm{mg} / 24$ hours, $2.25 \mathrm{mg} / 24$ hours, and $4 \mathrm{mg} / 24$ hours.

Abbreviations: RTG, rotigotine; Plo, placebo.

might make RTG a more favorable choice in treating patients compared to other less costly medications?

1. Compliance: PD is typically treated with several doses of medication per day. An increased frequency of medication doses per day is associated with a decrease in medication compliance. ${ }^{52}$ RTG provides once-a-day dosing, which appears to improve patient compliance, and adherence to an individual's drug regimen is necessary for successful treatment of PD. ${ }^{53}$ However, Tarrants and colleagues found that up to $47 \%$ of patients treated with oral PD medications had noncompliance measured as "below $80 \%$ medication possession ratio", which is a measure of how much more medication the patient had in their possession than if they took them as prescribed. ${ }^{54}$ An open-label, prospective, noninterventional study of 863 PD patients demonstrated high compliance with RTG. ${ }^{55}$ In this study, $97.9 \%$ of patients either never or rarely forgot to apply the daily RTG patch, and only $2.6 \%$ of patients forgot to apply the patch one or more times per week during the 4-month observation period after a titration period..$^{55}$ An open-label extension study by Oertel and colleagues reported that approximately 95\% of patients treated for RLS showed compliance with their RTG regimen over a 5-year period. ${ }^{45}$

2. Dysphagia: As a transdermal patch, RTG bypasses the gastrointestinal (GI) tract, making it a possible choice for patients with dysphagia. Additionally, the use of RTG 


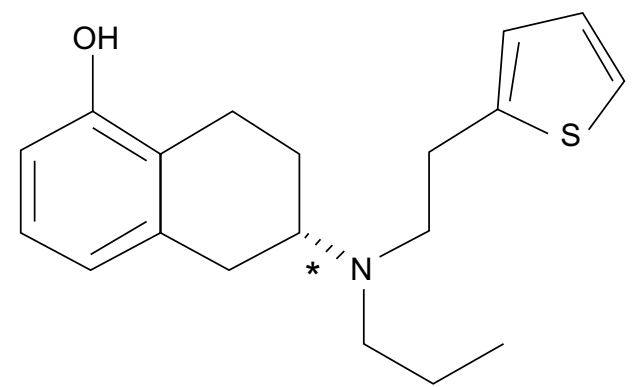

Figure I Structural formula of rotigotine.

Note: ${ }^{*}$ Chiral center.

avoids the need to schedule administration of medication around meals.

3. Gastroparesis: Since RTG bypasses first-pass metabolism, it is beneficial for patients who may have gastroparesis or other GI conditions that interfere with digestion and absorption of medication.

4. NMS: A post hoc analysis of data from the RECOVER study in PD patients shows promise for the potential of RTG to improve NMS of pain, mood disturbance, and sleep quality. ${ }^{31,34,56}$ One study also found a lower incidence of ICD with RTG. ${ }^{12}$ However, larger, prospective, blinded, and randomized studies designed to evaluate the role RTG for the treatment of NMS are needed.

5. Stable dosing: For PD and RLS patients who suffer from symptoms lasting throughout the day, RTG provides stable blood levels over 24 hours.

6. Renal impairment: No dose adjustment is required for renal impairment, including patients on dialysis.

Convenience of transdermal administration compared to PO, ability to use with general anesthesia, and enhanced absorption are some of the major reasons physicians and nurses prefer the use of RTG over other therapies for PD. ${ }^{57}$ In a cross-sectional, non-interventional study in clinical practice in Germany, 100 caregivers, 40 nurses, and 41 physicians caring for 147 patients (93\% taking levodopa) with PD answered questions about how RTG compares to oral PD medication in several domains, including swallowing dysfunction, nausea/vomiting, monitoring therapy, once-a-day dosing, dosing independent of meals, application of the medication to a sleeping patient, and caregiver effortsor clinical aspects. ${ }^{57}$ The mean total score of caregivers'/nurses' questionnaires was 1.32 (SD 0.67) and of physicians' questionnaires was 1.46 (SD 0.32), indicating a perceived advantage of the RTG transdermal patch over oral PD therapy. Physicians cited pharmaceutical form (patch) in 139 (95\%) cases as a rationale to prescribe. ${ }^{57}$

\section{Conclusion}

RTG has been found to be a safe and effective treatment for PD and RLS. Because of its transdermal application, RTG provides continuous dopamine delivery and steady plasma concentrations. RTG may be considered for use over other DAs in patients who prefer the ease of once-a-day dosing or who have an issue with the GI tract such as dysphagia or gastroparesis. A side effect unique to RTG that is not associated with other DAs is application site reaction; however, this is mild in most cases and resolves with discontinuation of the RTG transdermal patch. There is currently a lower irritation microemulsion-based RTG gel being studied and in the future, there may be formulations of RTG with less application site reactions. ${ }^{58}$ Future comparator studies could better characterize the benefits of the RTG against other generic alternatives, and to better inform the clinician when choosing a therapy for PD or RLS.

\section{Disclosure}

T Kesayan, JD Shaw, T Jones, and JS Staffetti have nothing to disclose and have no conflict of interest in this work. TA Zesiewicz receives grant funding from Edison Pharmaceuticals, Inc., Sagene Pharmaceuticals, Inc., the Friedreich's Ataxia Research Alliance, Osmotica Pharmaceutical Corp, Adamas Pharmaceuticals, Inc., and Baxter Pharmaceuticals, Inc. She has no other conflicts of interest in this work.

\section{References}

1. Elshoff J-P, Cawello W, Andreas J-O, Mathy F-X, Braun M. An update on pharmacological, pharmacokinetic properties and drug - drug interactions of rotigotine transdermal system in Parkinson's disease and restless legs syndrome. Drugs. 2015;75(5):487-501.

2. Giladi N, Boroojerdi B, Korczyn AD, Burn DJ, Clarke CE, Schapira AHV. Rotigotine transdermal patch in early Parkinson's disease: a randomized, double-blind, controlled study versus placebo and ropinirole. Mov Disord. 2007;22(16):2398-2404.

3. Rascol O, Perez-Lloret S. Rotigotine transdermal delivery for the treatment of Parkinson's disease. Expert Opin Pharmacother. 2009;10(4): 677-691.

4. Scheller D, Ullmer C, Berkels R, Gwarek M, Lübbert $H$. The in vitro receptor profile of rotigotine: a new agent for the treatment of Parkinson's disease. Naunyn Schmiedebergs Arch Pharmacol. 2009;379(1):73-86.

5. NEUPRO Prescribing Information. (C2015 UCB, Inc., Smyrna, GA 30080 All rights Reserv; 2015.

6. Benitez A, Edens H, Fishman J, Moran K, Asgharnejad M. Rotigotine transdermal system: developing continuous dopaminergic delivery to treat Parkinson's disease and restless legs syndrome. Ann N Y Acad Sci. 2014; 1329:45-66.

7. Kim JM, Chung SJ, Kim JW, et al; Asia Pacific Rotigotine Add-on Study Group. Rotigotine transdermal system as add-on to oral dopamine agonist in advanced Parkinson's disease: an open-label study. BMC Neurol. 2015;15(1):1-9.

8. Trenkwalder C, Benes H, Poewe W, et al; SP790 Study Group. Efficacy of rotigotine for treatment of moderate-to-severe restless legs syndrome: a randomised, double-blind, placebo-controlled trial. Lancet Neurol. 2008;7(7):595-604. 
9. Oertel WH, Benes H, Garcia-Borreguero D, et al; Rotigotine SP 709 Study Group. Efficacy of rotigotine transdermal system in severe restless legs syndrome: a randomized, double-blind, placebocontrolled, six-week dose-finding trial in Europe. Sleep Med. 2008;9(3):228-239.

10. Hening WA, Allen RP, Ondo WG, et al; SP792 Study Group. Rotigotine improves restless legs syndrome: a 6-month randomized, double-blind, placebo-controlled trial in the United States. Mov Disord. 2010;25(11):1675-1683.

11. Oertel WH, Benes H, Garcia-Borreguero D, et al; Rotigotine SP710 Study Group. One year open-label safety and efficacy trial with rotigotine transdermal patch in moderate to severe idiopathic restless legs syndrome. Sleep Med. 2008;9(8):865-873.

12. Garcia-Ruiz PJ, Martinez Castrillo JC, Alonso-Canovas A, et al. Impulse control disorder in patients with Parkinson's disease under dopamine agonist therapy: a multicentre study. J Neurol Neurosurg Psychiatry. 2014;85(8):840-844.

13. Weintraub D, Siderowf AD, Potenza MN, et al. Association of dopamine agonist use with impulse control disorders in Parkinson disease. Arch Neurol. 2006;63(7):969-973.

14. Grinberg LT, Rueb U, Alho AT, Heinsen H. Brainstem pathology and non-motor symptoms in PD. J Neurol Sci. 2010;289(1-2):81-88.

15. Damier P, Hirsch EC, Agid Y, Graybiel AM. The substantia nigra of the human brain: II. Patterns of loss of dopamine-containing neurons in Parkinson's disease. Brain. 1999;122(8):1437-1448.

16. Hirsch E, Graybiel AM, Agid YA. Melanized dopaminergic neurons are differentially susceptible to degeneration in Parkinson's disease. Nature. 1988;334(6180):345-348

17. German DC, Manaye K, Smith WK, Woodward DJ, Saper CB. Midbrain dopaminergic cell loss in Parkinson's disease: computer visualization Ann Neurol. 1989;26(4):507-514.

18. Sullivan KL, Ward CL, Hauser RA, Zesiewicz TA. Prevalence and treatment of non-motor symptoms in Parkinson's disease. Parkinsonism Relat Disord. 2007;13(8):545.

19. Zesiewicz TA, Evatt ML. Potential influences of complementary therapy on motor and non-motor complications in Parkinson's disease. CNS Drugs. 2009;23(10):817-835.

20. Güldenpfennig WM, Poole KH, Sommerville KW, Boroojerdi B. Safety, tolerability, and efficacy of continuous transdermal dopaminergic stimulation with rotigotine patch in early-stage idiopathic Parkinson disease. Clin Neuropharmacol. 2015;28(3):106-110.

21. Jankovic J, Watts RL, Martin W, Boroojerdi B. Transdermal rotigotine: double-blind, placebo-controlled trial in Parkinson disease. Arch Neurol. 2007;64(5):676-682.

22. Parkinson Study Group. A controlled trial of rotigotine monotherapy in early Parkinson's disease. Arch Neurol. 2003;60:1721-1728.

23. Watts RL, Jankovic J, Waters C, Rajput A, Boroojerdi B, Rao J. Randomized, blind, controlled trial of transdermal rotigotine in early Parkinson disease. Neurology. 2007;68(4):272-276.

24. Oertel WH, Beneš H, Garcia-Borreguero D, et al. Rotigotine transdermal patch in moderate to severe idiopathic restless legs syndrome: a randomized, placebo-controlled polysomnographic study. Sleep Med. 2010;11(9):848-856.

25. Trenkwalder C, Kies B, Rudzinska M, et al; Recover Study Group. Rotigotine effects on early morning motor function and sleep in Parkinson's disease: a double-blind, randomized, placebo-controlled study (RECOVER). Mov Disord. 2011;26(1):90-99.

26. LeWitt PA, Lyons KE, Pahwa R; SP 650 Study Group. Advanced Parkinson disease treated with rotigotine transdermal system: PREFER Study. Neurology. 2007;68(16):1262-1267.

27. Poewe WH, Rascol O, Quinn N, et al; SP 515 Investigators. Efficacy of pramipexole and transdermal rotigotine in advanced Parkinson's disease: a double-blind, double-dummy, randomised controlled trial Lancet Neurol. 2007;6(6):513-520.

28. Nomoto M, Mizuno Y, Kondo T, et al. Transdermal rotigotine in advanced Parkinson's disease: a randomized, double-blind, placebocontrolled trial. J Neurol. 2014;261(10):1887-1893.
29. Zesiewicz TA, Sullivan KL, Hauser RA. Nonmotor symptoms of Parkinson's disease. Expert Rev Neurother. 2006;6(12):1811-1822.

30. Zesiewicz TA, Martinez-Martin P. Effects of rotigotine transdermal system on non-motor symptoms in Parkinson's disease: an overview. Expert Rev Neurother. 2013;13(12):1329-1342.

31. Ray Chaudhuri K, Martinez-Martin P, Antonini A, et al. Rotigotine and specific non-motor symptoms of Parkinson's disease: post hoc analysis of RECOVER. Parkinsonism Relat Disord. 2013;19(7):660-665.

32. Chaudhuri KR, Schapira AHV. Non-motor symptoms of Parkinson's disease: dopaminergic pathophysiology and treatment. Lancet Neurol. 2009;8(5):464-474.

33. Barone P, Antonini A, Colosimo C, et al; PRIAMO Study Group. The PRIAMO study: a multicenter assessment of nonmotor symptoms and their impact on quality of life in Parkinson's disease. Mov Disord. 2009;24(11):1641-1649.

34. Kassubek J, Chaudhuri KR, Zesiewicz T, et al. Rotigotine transdermal system and evaluation of pain in patients with Parkinson's disease: a post hoc analysis of the RECOVER study. BMC Neurol. 2014;14:42.

35. Giladi N, Fichtner A, Poewe W, Boroojerdi B. Rotigotine transdermal system for control of early morning motor impairment and sleep disturbances in patients with Parkinson's disease. J Neural Transm. 2010;117(12):1395-1399.

36. Pagonabarraga J, Piñol G, Cardozo A, et al. Transdermal rotigotine improves sleep fragmentation in Parkinson's disease: results of the multicenter, prospective SLEEP-FRAM study. Parkinsons Dis. 2015;2015: $1-7$.

37. Walters AS, LeBrocq C, Dhar A, et al; International Restless Legs Syndrome Study Group. Validation of the International Restless Legs Syndrome Study Group rating scale for restless legs syndrome. Sleep Med. 2003;4(2):121-132.

38. Allen RP, Picchietti DL, Garcia-Borreguero D, et al; International Restless Legs Syndrome Study Group. Restless legs syndrome/WillisEkbom disease diagnostic criteria: updated International Restless Legs Syndrome Study Group (IRLSSG) consensus criteria - history, rationale, description, and significance. Sleep Med. 2014;15(8):860-873.

39. Merlino G, Serafini A, Robiony F, Valente M, Gigli GL. Restless legs syndrome: differential diagnosis and management with rotigotine. Neuropsychiatr Dis Treat. 2009;5:67-80.

40. Inoue Y, Shimizu T, Hirata K, et al; Rotigotine Trial Group. Efficacy and safety of rotigotine in Japanese patients with restless legs syndrome: a phase 3, multicenter, randomized, placebo-controlled, double-blind, parallel-group study. Sleep Med. 2013;14(11):1085-1091.

41. Stiasny-Kolster K, Kohnen R, Schollmayer E, Möller JC, Oertel WH. Patch application of the dopamine agonist rotigotine to patients with moderate to advanced stages of restless legs syndrome: a double-blind, placebo-controlled pilot study. Mov Disord. 2004;19(12):1432-1438.

42. Trenkwalder C, Benes H, Grote L, et al; CALDIR Study Group. Cabergoline compared to levodopa in the treatment of patients with severe restless legs syndrome: results from a multi-center, randomized, active controlled trial. Mov Disord. 2007;22(5):696-703.

43. Allen RP, Earley CJ. Augmentation of the restless legs syndrome with carbidopa/levodopa. Sleep. 1996;19(3):205-213.

44. Beneš H, García-Borreguero D, Ferini-Strambi L, Schollmayer E, Fichtner A, Kohnen R. Augmentation in the treatment of restless legs syndrome with transdermal rotigotine. Sleep Med. 2012;13(6): 589-597.

45. Oertel W, Trenkwalder C, Beneš H, et al; García-Borreguero D; SP710 Study Group. Long-term safety and efficacy of rotigotine transdermal patch for moderate-to-severe idiopathic restless legs syndrome: a 5-year open-label extension study. Lancet Neurol. 2011;10(8):710-720.

46. Garcia-Borreguero D, Kohnen R, Silber MH, et al. The long-term treatment of restless legs syndrome/Willis-Ekbom disease: evidencebased guidelines and clinical consensus best practice guidance: a report from the International Restless Legs Syndrome Study Group. Sleep Med. 2013;14(7):675-684.

47. Högl B, Oertel WH, Stiasny-Kolster K, et al. Treatment of moderate to severe restless legs syndrome: 2-year safety and efficacy of rotigotine transdermal patch. BMC Neurol. 2010;10:86. 
48. Allen R, Oertel W, Walters A, et al. Relation of the International Restless Legs Syndrome Study Group rating scale with the Clinical Global Impression Severity Scale, the restless legs syndrome 6-item questionnaire, and the restless legs syndrome-quality of life questionnaire. Sleep Med. 2013;14(12):1375-1380.

49. Benhaddi HGH. Cost utility analysis of rotigotine transdermal patch in early stage Parkinson's disease in Scotland. Poster Presented at: ISPOR 13th Annu Eur Congr Prague; 2010; Czech Republic: 1.

50. Aguirre A, Benitez ABH. Cost effectiveness of rotigotine transdermal patch in patients with advanced Parkinson's disease in Mexico. Poster Presented at: ISPOR 13th Annu Eur Congr Prague; 2010; Czech Republic: 1.

51. Mizuno Y, Nomoto M, Hasegawa K, et al; Rotigotine Trial Group. Rotigotine vs ropinirole in advanced stage Parkinson's disease: a doubleblind study. Parkinsonism Relat Disord. 2014;20(12):1388-1393.

52. Saini SD, Schoenfeld P, Kaulback K, Dubinsky MC. Effect of medication dosing frequency on adherence in chronic diseases. Am J Manag Care. 2009;15(6):e22-e33.

53. Grosset KA, Bone I, Grosset DG. Suboptimal medication adherence in Parkinson's disease. Mov Disord. 2005;20(11):1502-1507.
54. Tarrants ML, Denarié MF, Castelli-Haley J, Millard J, Zhang D. Drug therapies for Parkinson's disease: a database analysis of patient compliance and persistence. Am J Geriatr Pharmacother. 2010;8(4): 374-383.

55. Schnitzler A, Leffers KW, Häck HJ. High compliance with rotigotine transdermal patch in the treatment of idiopathic Parkinson's disease. Parkinsonism Relat Disord. 2010;16(8):513-516.

56. Ghys L, Surmann E, Whitesides J, Boroojerdi B. Effect of rotigotine on sleep and quality of life in Parkinson's disease patients: post hoc analysis of RECOVER patients who were symptomatic at baseline. Expert Opin Pharmacother. 2011;12(13):1985-1998.

57. Sieb JP, Themann P, Warnecke T, et al. Caregivers' and physicians' attitudes to rotigotine transdermal patch versus oral Parkinson's disease medication: an observational study. Curr Med Res Opin. 2015;31(5): 967-974.

58. Mu H, Ma P, Zhang W, Wang A, Wang W, Sun K. Lower irritation microemulsion-based rotigotine gel: formulation optimization and in vitro and in vivo studies. Int J Nanomedicine. 2015;10:633-644.
Degenerative Neurological and Neuromuscular Disease

\section{Publish your work in this journal}

Degenerative Neurological and Neuromuscular Disease is an international, peer-reviewed, open access journal focusing on research into degenerative neurological and neuromuscular disease, identification of therapeutic targets and the optimal use of preventative and integrated treatment interventions to achieve improved outcomes, enhanced

\section{Dovepress}

survival and quality of life for the patient. The manuscript management system is completely online and includes a very quick and fair peer-review system. Visit http://www.dovepress.com/testimonials.php to read real quotes from published authors. 